\title{
POPULATION GROWTH IN THE BORDER VILLAGES OF SREM, SERBIA
}

Tamara Lukić, Milka Bubalo - Živković, Bojan Đerčan, Gordana Jovanović

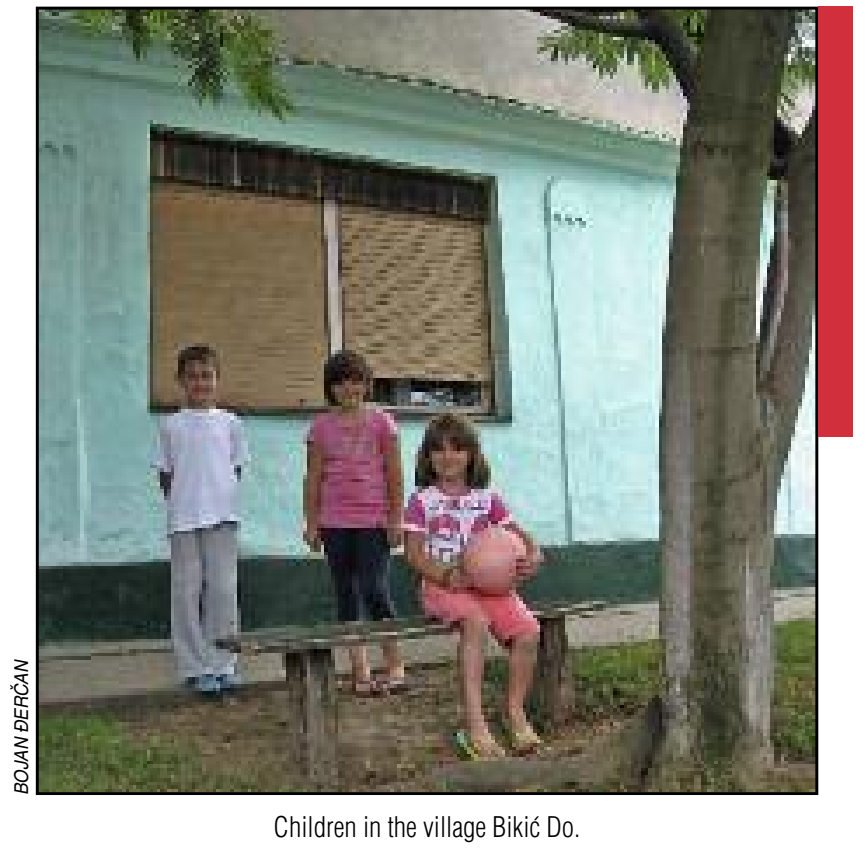




\section{Population Growth in the Border Villages of Srem, Serbia}

DOI: http://dx.doi.org/10.3986/AGS54103

UDC: $911.373: 314.116(497.11)$

COBISS: 1.01

ABSTRACT: Population growth in the border villages of Srem (Vojvodina, Serbia) has been analysed in this paper, with the goal of explaining how and why it differed from other areas in the region. Special attention has been paid to the 1990s, because these villages became part of a border region and a high level of migration on the territory of the former Yugoslavia occurred, much of it through this territory. The results of the research are derived from literary resources and applying mathematical and statistical procedures in the processing of data received from the Statistical Office of the Republic of Serbia. They were checked on the field via a questionnaire. This paper is significant because it enriches knowledge about villages of Srem, the municipality of Šid and population trends at the end of the $20^{\text {th }}$ century.

KEY WORDS: Serbia, Srem, Municipality of Šid, population growth, immigration, border rural settlements, ethnic composition

The article was submitted for publication July 1,2011.

ADDRESSES:

Tamara Lukić, Ph. D.

Faculty of Science

University of Novi Sad

Trg Dositeja Obradovića 3, 21000 Novi Sad, Serbia

E-mail: snstamara@yahoo.com

Milka Bubalo - Živković, Ph. D.

Faculty of Science

University of Novi Sad

Trg Dositeja Obradovića 3, 21000 Novi Sad, Serbia

E-mail:miladin32dus@yahoo.com

\section{Bojan Đerčan}

Faculty of Science

University of Novi Sad

Trg Dositeja Obradovića 3, 21000 Novi Sad, Serbia

E-mail: bojandjercan@yahoo.co.uk

Gordana Jovanović, Ph. D.

Faculty of Science

University of Novi Sad

Trg Dositeja Obradovića 3, 21000 Novi Sad, Serbia

E-mail: gordanagjovanovic@yahoo.com 


\section{Introduction}

With the collapse of Yugoslavia at the beginning of the 1990s, new borders were established, and consequently border villages. Literary sources (Penev 1994; Kovačević 2006; Kovačević et al. 2009; Ivkov-Džigurski et al. 2010) mention problems of the new border villages in Serbia. Among them in particular are demographic problems, such as depopulation, emigration, the ageing of the populace etc. (Vujadinović et al. 2010). These problems also appear in other parts of Europe, according to other sources (Machold et al. 2002; Ni Laoire 2000; Stockdale 2002, 2006).

This research on the population trends in the border villages of Srem had as its goal the determination of the parameters of the population movement and thereby illustrating to what extent drawing the border had in demographic sense positive or negative influence on these villages. For that reason, particular attention has been paid to the period between the last two censuses. Đurđev et al. (2004) stated that according to the 2002 census refugees and displaced persons from the region of the former Yugoslavia caused regional differences in the growth rate of the population of Vojvodina. The share of this category of people in the total population in the municipality of Šid, in 2002, had the highest value at $23.4 \%$. Given that the wartime operations in Croatia and Bosnia and Herzegovina stopped in the mid 1990's, it must be assumed that there were even more of people present at that time but many of them lost their refugee status by obtaining citizenship.

Srem, one of three regional units of the Autonomous Province of Vojvodina, has fourteen border settlements (VGI 1982; 1982a; 1982b; 1983). From that number, two border villages (Neštin and Vizić) are

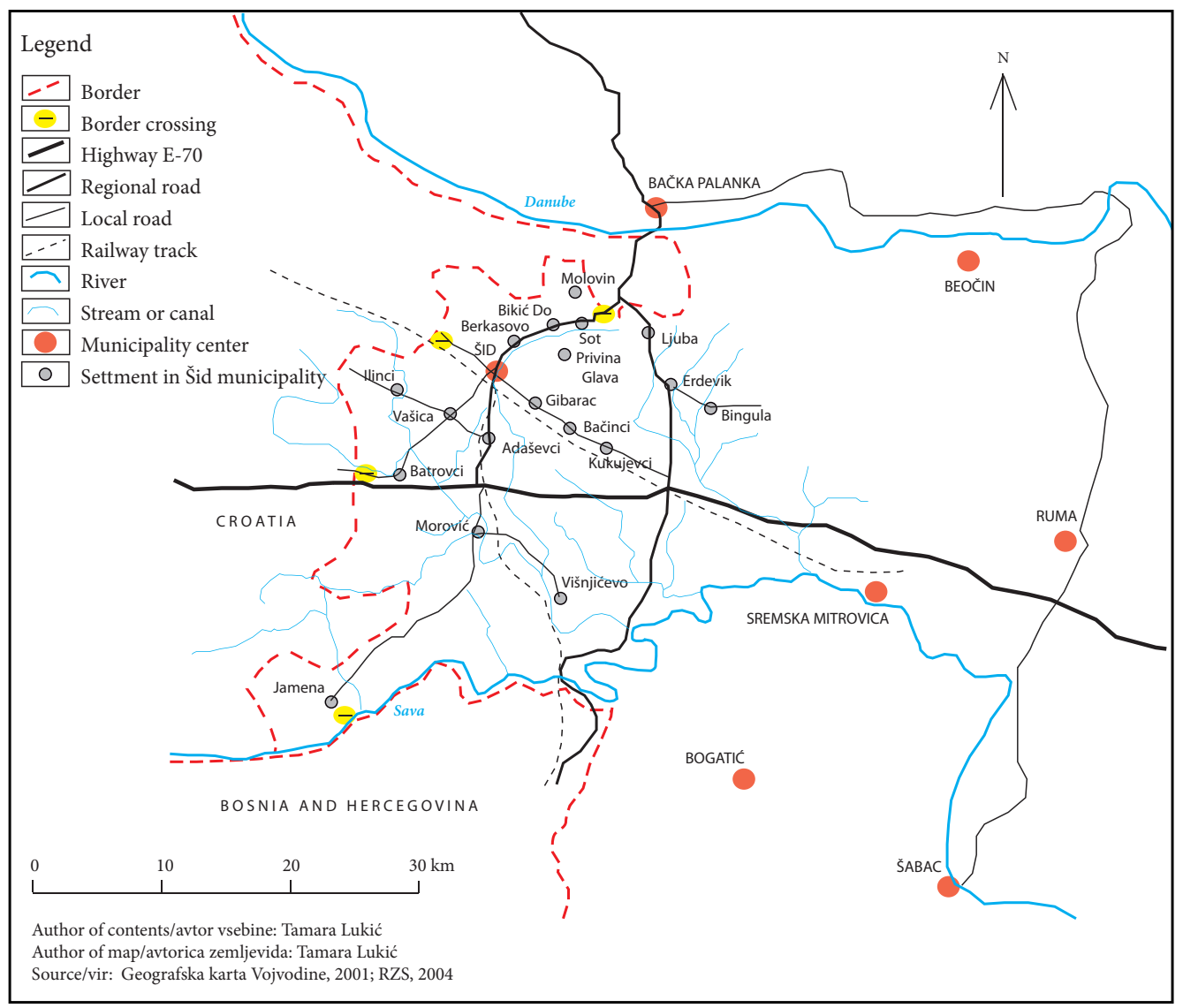

Figure 1: Geographic position of settlements in the municipality of Šid. 
part of the municipality of Bačka Palanka (Bogdanović et al. 1997), one (Sremska Rača) is located in the municipality of Sremska Mitrovica (Ćurčić et al. 2002) and eleven settlements (Figure 1) are part the municipality of Šid (Ćurčić 2001). Considering the fact that most of the settlements are located in the municipality of Šid, because of the factors of standardisation of local self-management performance, this paper will be focused only on these villages. According to the categorisation of settlements by Statistical Office of the Republic of Serbia, only one of eleven settlements in the municipality of Šid has been deemed to be a 'town settlement' (Statistical Office of the Republic of Serbia, 2004a). The multi-functionality of this settlement, which is simultaneously the municipality centre, puts other villages into an unequal position. The administrative and management functions of the settlement imply the presence of other functions, e.g. educational, cultural, etc., and in that way positively modify the demographic situation. For that reason, Šid will be excluded from the analysis, and only village settlements will be compared.

\section{Material and methods}

This paper is the result of analyses of data received at the Statistical Office of the Republic of Serbia. Data were illustrated by drawing maps: relevant content was extracted from existing figures, in order to form the desired maps.

The results of the research were verified on the field by conducting a questionnaire for one hundred respondents, i.e. an interview was conducted with ten respondents in each village. Respondents were between the ages of 19 and 65, and both sexes were equally represented. The aim of the interview was to explain some occurrences observed in the analysis and processing of statistical data. For that reason, the questions were of an open character, and answers to them were not predictable.

\section{Results and discussion}

The analyses of the population trends should find and explain differences in the movements of people in the border villages of the municipality of Šid in the period from the census in 1991 to the census in 2002. In addition to the explanation will be a discussion of the ethnic structure of the population, and the results of the conducted interview.

\subsection{Population figures}

An international recommendation was accepted that the census be carried out every ten years, in the first year of the decade; this has been the practice since 1961 (Stanković 2006). Because the census that should have been carried out in 2001 was made in 2002, the comparability of census data was seriously damaged; nevertheless, certain tendencies in population trends could be observed (Đurđev et al. 2010).

According to the 1991 census, the population of the border villages in this area ranged from 299 inhabitants, registered in Bikić Do, to 2105 inhabitants in Morović. Differences in the population sizes of villages were preserved in the most recent census: in 2002, they ranged from 298 inhabitants in Molovin to 2164 inhabitants in Morović. Analyses of the geographical position and relief characteristics show that border villages with smaller populations are located in the northern half of the border, i.e. on the slopes of the Fruška Gora mountain and in river valleys of its streams. Only Batrovci differs from this trend; it is located on the Bosut River, somewhat north of the E-70 motorway. None of the villages has changed the category of size to which they belonged, but within the categories certain changes occurred (Table 1).

Table 1: Classification of border villages of the municipality of Šid according to the size and according to the 1991 and 2002 censuses.

\begin{tabular}{lccccc}
\hline Census & $\leq 500$ & $500-1000$ & $1000-1500$ & $1500-2000$ & $2000 \geq$ \\
\hline 1991 & 3 & 3 & 2 & 1 & 1 \\
2002 & 3 & 3 & 2 & 1 & 1 \\
\hline
\end{tabular}

Source: Statistical Office of the Republic of Serbia, 2004a 
In the period when the aforementioned border villages were not border villages, the population decreased in all villages from the 1981 census to the 1991 census. That decrease was $-9.2 \%$ in average and was three times higher than the value calculated for the municipality Šid $(-3.1 \%)$. The decrease in the population ranged from $-0.7 \%$ in Bikić Do to $-18.7 \%$ in Molovin (Figure 2). There was no decrease in the number of inhabitants in the town of Šid. Characteristic migrations, for the decade of 1981-1991, which were initiated in earlier decades by the processes of urbanisation, industrialisation and suburbanisation, continued to occur (Lukić 2010,2). The development of secondary and tertiary businesses in the municipal and regional centres, such as Šid, increased the population from 1981 to 1991 by $5.8 \%$.

However, in the period from 1991 to 2002, four of the ten observed villages showed increases in population (Figure 2). During the analysis of the geographic position of these border villages, the conclusion was drawn that population number increased in villages that are located on the highway M 18.1 (Bikić Do and Berkasovo), which connects Šid and Bačka Palanka, and in villages that are located on crossroads for other municipality villages (Vašica, Morović). Border villages that did not have an increase in population are not located on these transit lines. The population decreases in those villages ranged from $-0.4 \%$ in Sot to $-12.7 \%$ in Jamena. Consequently, it was concluded that, although a decrease was noticed, its intensity is smaller than in the decade that preceded (Table 2).

The increase in the number of inhabitants in the border villages $(2.2 \%)$ is less than a fourth than that on the municipal level (9.8\%). Given that the number of inhabitants in the town of Šid increased by $15.2 \%$, it can be concluded that the municipal centre was more attractive for settlement than other municipal rural settlements that were not on the border.

\subsection{Population trend}

Changes of the values of population were explained in parameters of population trends, i.e. rates of natural population growth and migration balance were calculated.

\subsubsection{Natural movement}

According to the rate of natural population growth, among the border villages of the municipality of Šid there are three types of villages: villages that did not register positive natural population growth in the observed period, from 1991 to 2001 (Vašica, Ilinci, Jamena and Sot), villages that registered positive natural population growth in one year (Batrovci, Berkasovo and Morović) and villages that had positive natural population growth in four of ten years (Molovin, Ljuba and Bikić Do) (Table 3).

Table 2: Population number of border villages in the municipality of Šid.

\begin{tabular}{|c|c|c|c|c|c|c|c|}
\hline \multirow[t]{2}{*}{ Settlement } & \multicolumn{3}{|c|}{ Year } & \multicolumn{2}{|c|}{ Change in absolute number } & \multicolumn{2}{|c|}{ Change in relative number (in \%) } \\
\hline & 1981 & 1991 & 2002 & $1991 / 1981$ & 2002/1991 & $1991 / 1981$ & 2002/1991 \\
\hline Batrovci & 464 & 399 & 361 & -65 & -38 & -16.3 & -10.5 \\
\hline Berkasovo & 1217 & 1103 & 1258 & -114 & 155 & -10.3 & 12.3 \\
\hline Bikić Do & 301 & 299 & 336 & -2 & 37 & -0.7 & 11.0 \\
\hline Vašica & 1740 & 1636 & 1758 & -104 & 122 & -6.4 & 6.9 \\
\hline Ilinci & 1011 & 883 & 843 & -128 & -40 & -14.5 & -4.7 \\
\hline Jamena & 1577 & 1399 & 1241 & -178 & -158 & -12.7 & -12.7 \\
\hline Ljuba & 639 & 585 & 563 & -54 & -22 & -9.2 & -3.9 \\
\hline Molovin & 362 & 305 & 298 & -57 & -7 & -18.7 & -2.3 \\
\hline Morović & 2196 & 2105 & 2272 & -91 & 167 & -4.3 & 7.4 \\
\hline Sot & 900 & 819 & 816 & -81 & -3 & -9.9 & -0.4 \\
\hline Villages* & 10407 & 9533 & 9746 & -874 & 213 & -9.2 & 2.2 \\
\hline Town (Šid) & 13450 & 14275 & 16834 & 825 & 2559 & 5.8 & 15.2 \\
\hline Municipality** & 37459 & 36317 & 40255 & -1142 & 3938 & -3.1 & 9.8 \\
\hline
\end{tabular}

Note: Villages ${ }^{\star}-10$ border villages of the municipality of Šid; Municipality ${ }^{\star \star}$ - all (19) settlements of the municipality of Šid; Source: Statistical Office of the Republic of Serbia, 2004a; own calculations. 

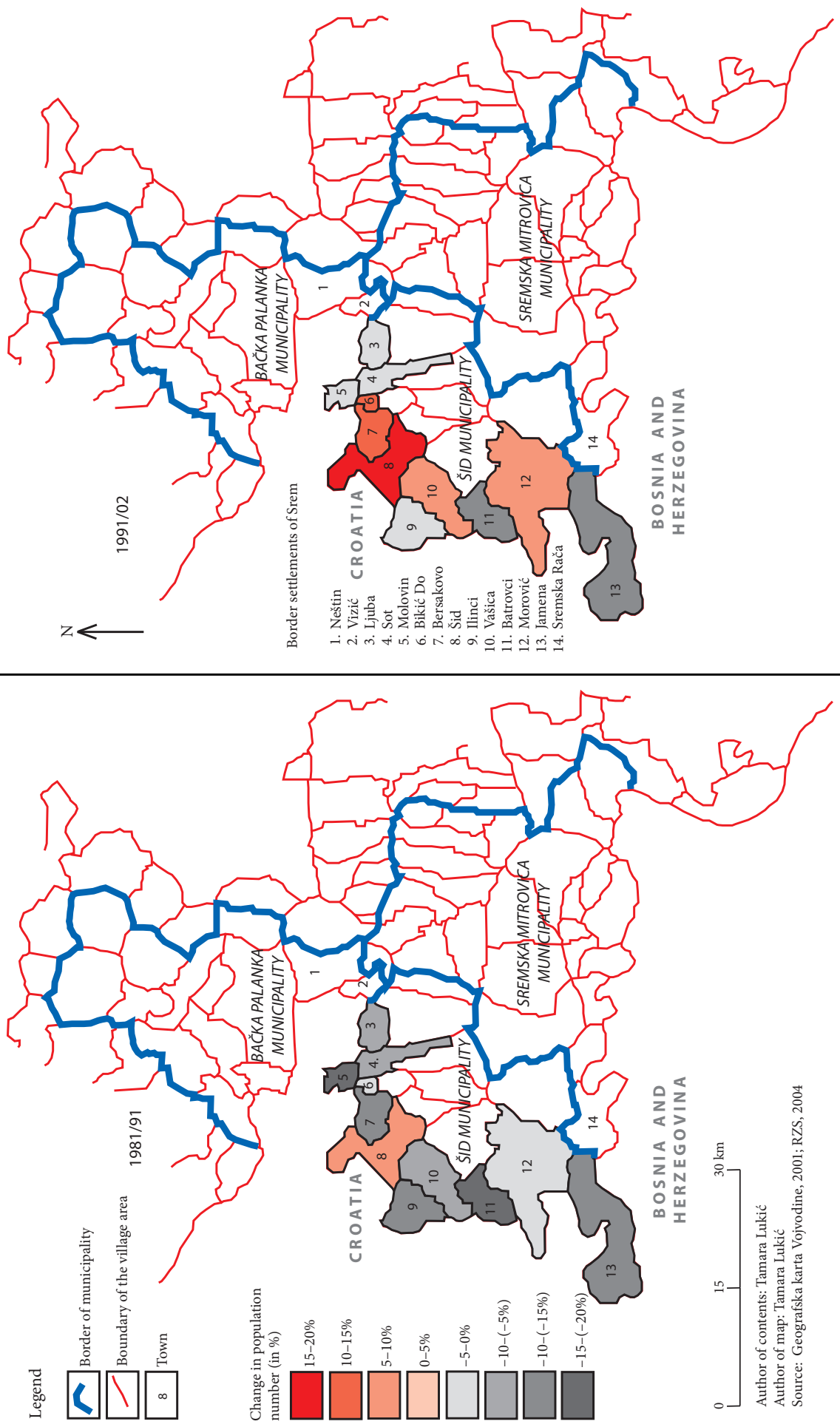
Table 3: Changes of the rate of natural population growth (in \%o) in border villages of the municipality of Šid in the period between 1991 and 2001.

\begin{tabular}{|c|c|c|c|c|c|c|c|c|c|c|c|}
\hline Settlement & 1991 & 1992 & 1993 & 1994 & 1995 & 1996 & 1997 & 1998 & 1999 & 2000 & 2001 \\
\hline Batrovci & -4.4 & -6.7 & -13.5 & -18.3 & -18.6 & -7.1 & 4.8 & -12.2 & -24.7 & -20.1 & -20.2 \\
\hline Berkasovo & -5.0 & -8.4 & -5.1 & -5.1 & -3.5 & -11.3 & -17.6 & 5.3 & -20.6 & -13.6 & -13.4 \\
\hline Bikić Do & -19.9 & -13.3 & 0.0 & -10.0 & -3.3 & -3.3 & -3.3 & 10.0 & 10.0 & 10.0 & 6.6 \\
\hline Vašica & -1.7 & -6.4 & -7.0 & -4.7 & -9.5 & -7.8 & -12.0 & -9.7 & -7.9 & -14.1 & -14.6 \\
\hline Ilinci & -17.0 & -12.2 & -2.1 & -11.5 & -18.0 & -18.2 & -6.5 & -8.8 & -20.1 & -6.8 & -17.1 \\
\hline Jamena & -7.1 & -12.3 & 0.0 & -10.6 & -8.8 & -11.6 & -9.7 & -11.2 & -14.8 & -5.7 & -14.5 \\
\hline Ljuba & 6.3 & -11.1 & -9.6 & -9.7 & -13.1 & -16.5 & 0.0 & 1.7 & -1.7 & 3.4 & 3.4 \\
\hline Molovin & 2.8 & -8.6 & -8.7 & 0.0 & -15.0 & 3.1 & 0.0 & -12.7 & -6.4 & 3.3 & 6.6 \\
\hline Morović & -3.7 & -7.8 & -5.1 & -6.0 & 0.0 & 3.7 & -11.7 & -5.7 & -6.1 & -6.2 & 0.0 \\
\hline Sot & -13.5 & -12.5 & -14.9 & -11.5 & -2.3 & -10.6 & -14.2 & -3.6 & -13.3 & -19.5 & -22.0 \\
\hline Villages* & -6.3 & -9.9 & -6.6 & -8.7 & -9.2 & -8.0 & -7.0 & -4.7 & -10.6 & -6.9 & -8.5 \\
\hline Town (Šid) & 2.1 & 0.2 & 2.4 & -1.5 & 1.2 & 1.4 & -1.1 & -2.1 & -1.4 & -1.7 & -1.0 \\
\hline Municipality** & -2.0 & -4.9 & -3.0 & -4.8 & -4.1 & -3.3 & -5.1 & -3.1 & -6.1 & -5.2 & -5.4 \\
\hline
\end{tabular}

Note: Villages ${ }^{\star}-10$ border villages of the municipality of Šid; Municipality ${ }^{\star \star}$ - all (19) settlements of the municipality of Šid; Source: Statistical Office of the Republic of Serbia, 2004a; Statistical Office of the Republic of Serbia, 2010; own calculations

From the border villages of Srem that were singled out as those in which the population increased, only Bikić Do distinguished itself also as one in which positive natural population growth was registered and has occurred continuously during previous four years (Figure 3). In other border villages, the changes of population were mainly influenced by mechanical population movement.

The townžs population growth rate in the first half of the observed decade, except for 1994, had a positive value, followed by a negative one. Positive population growth could not compensate for the volumes of negative rates in municipal settlements, so the population growth rate at the municipal level, had permanent negative values in the observed period, showing a negative growth tendency. Thus, population growth could be the result of a solely mechanical movement of population, i.e. immigration.

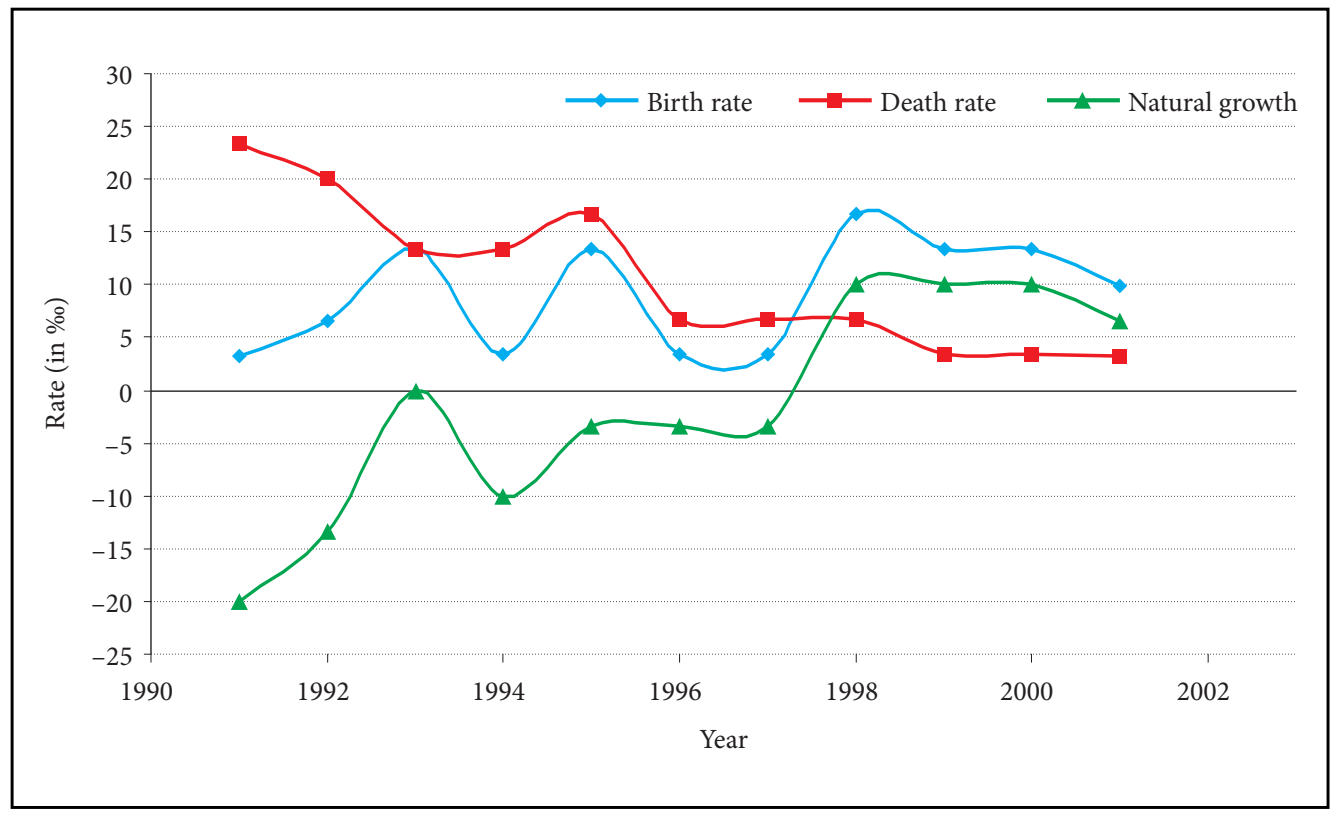

Figure 3: Changes of the rate of natural population growth of Bikić Do in the period between 1991 and 2001 (Statistical Office of the Republic of Serbia, 2010; own calculations). 


\subsubsection{Migrations}

Migration into Europe has been on the rise in recent decades (Hooghe et al. 2008; Meuleman et al. 2009). Regions of the former Yugoslavia, to which the border villages of the municipality of Šid also belong, have followed this trend in their own way. This is the best illustrated by analysing the proportions of immigrant populations. According to the 2002 census, the immigrant population constitutes the majority in the municipality of Šid (56.3\%), as well as in the town (57.1\%) and in the border villages (52.9\%). Specifically, the portion of the population that has lived in the border villages of the municipality of Šid from their birth, the so-called natives, differs greatly, ranging from $36.7 \%$ in Morović to $63.7 \%$ in Ljuba (Table 4). Border villages in the municipality of Šid in which less than $50 \%$ of the people are natives are those villages that have increased their populations. From other border villages, only Sot is part of this group.

In all the border villages of the municipality of Šid, the majority of the immigrant population is comprised of people who have migrated from the territories of former Yugoslav republics, other than Serbia (Lukić and Matijević 2006). Except the village Ljuba, their portion in the total immigrant population exceeds $50 \%$ (Table 5). The share of the immigrant population on the municipal level $(63.3 \%)$ and on at the town level $(52.1 \%)$, is lower than the share in the border villages of the municipality of Šid (69.7\%). Refugees are those people who do not plan to migrate, but they are suddenly forced to do so, and consequently they make little preparation and generally do not know their destination (O'Docherty Madrayo 1988). In the interviews, it was concluded that for most of the immigrant population, and almost $100 \%$ of the female respondents, the main reason for migration was the fear of potential violence, i.e. war trauma. This fact is concurrent with the research results Lim et al $(2007 ; 1542)$ and Vrecer $(2010,499)$.

In the questionnaire, one of the questions referred to the factors that crucially affected the immigrants' choice to migrate to a certain village. The answers were different, but among them the most frequent were the following: in some villages they already had relatives, rarely friends; in some villages, the prices of real estate were more favourable; some villages, for example on the slopes of the Fruška Gora mountain, had similar landscape characteristics to the area they came from, i.e. for those from hilly terrain, it is more difficult to adjust to life on the plains and vice versa; personal reasons, for example forming the family, etc. Some of these answers coincide with the results of Pilkington (1998) and Lukić and Nikitović (2004).

In some of the border villages, significant portions of migrants who did not come from the territories of former Yugoslavia stand out. For example, 43.3\% of migrants in Bikić Do and 35.3\% in Berkasovo are settled populations of intra-municipal migrations. In the interviews, it was stated that the reason many migrated from other municipal villages to Bikić Do or to Berkasovo was that these places are populated by Rusyn minority, and some of the respondents think that Rusyns settle in these villages for the reason of marriage.

In Ljuba, it has been recorded that more than one third of the settled population (33.5\%) are migrants who settled from the territories of other municipalities in the Republic of Serbia. In interviews it was found

Table 4: Share of natives in total population, according the census 2002 in the border villages of the municipality of Šid.

\begin{tabular}{|c|c|c|c|c|c|}
\hline \multirow[t]{2}{*}{ Settlement } & \multirow[t]{2}{*}{ Sum } & \multicolumn{2}{|c|}{ Natives } & \multicolumn{2}{|c|}{ Immigrants } \\
\hline & & Number & $\%$ & Number & $\%$ \\
\hline Batrovci & 320 & 193 & 60.3 & 127 & 39.7 \\
\hline Berkasovo & 1228 & 475 & 38.7 & 753 & 61.3 \\
\hline Bikić Do & 336 & 158 & 47.0 & 178 & 53.0 \\
\hline Vašica & 1717 & 842 & 49.0 & 875 & 51.0 \\
\hline Ilinci & 827 & 478 & 57.8 & 349 & 42.2 \\
\hline Jamena & 1130 & 586 & 51.9 & 544 & 48.1 \\
\hline Ljuba & 559 & 356 & 63.7 & 203 & 36.3 \\
\hline Molovin & 298 & 170 & 57.0 & 128 & 43.0 \\
\hline Morović & 2164 & 794 & 36.7 & 1370 & 63.3 \\
\hline Sot & 791 & 360 & 45.5 & 431 & 54.5 \\
\hline Villages* & 9370 & 4412 & 47.1 & 4958 & 52.9 \\
\hline Town (Šid) & 16311 & 7004 & 42.9 & 9307 & 57.1 \\
\hline Municipality** & 38973 & 17019 & 47.3 & 21954 & 56.3 \\
\hline
\end{tabular}

Note: Villages ${ }^{\star}-10$ border villages of the municipality of Šid; Municipality* - all (19) settlements of the municipality of Šid; Source: Statistical Office of the Republic of Serbia, 2004b; own calculations 
out that Ljuba is settled by the Slovak minority, and that these migrants have origins in the municipality Kovačica (Padina and Kovačica settlements), Bački Petrovac (Bački Petrovac, Gložan and Silbaš setllements), Beočin (the village of Lug), Stara Pazova (Stara Pazova settlement) and Bač (the village of Selenča) and others, i.e. from municipalities settled by Slovaks. Moreover, while talking with the local population, it was determined that Slovaks cherish their relations with their mother-land and that part of the marriage migrations happen between Ljuba and villages in Slovakia. This directly explains the fact that this village has the highest percent of people from the territories of other countries compared to other border villages of the municipality Šid (Table 5).

In the second place according to the level of migrant origin are those that have settled in the area as a result of intra-municipal migration. Such people represent nearly one in three immigrants $(30.3 \%)$ in the town of Šid and one in five in the municipality (21.0\%). According to Lukić and Tošić $(2011,322)$, the current economic reforms, the process of deindustrialisation and the privatisation of larger enterprises have been significant for changes in the commuting flows (directions and structure). The increase in the number of commuters in Serbia is one of the ways in which the population is adapting and overcoming the problems of unemployment and the lack of adequate jobs in the local milieu, while simultaneously maintaining of commuting as the form of mobility that prevents further concentration of people in urban centres. The features of a municipality attract residents, but they change their place of residence towards other municipal settlements 'in search of bread'. Based on the interviews, it was found that the jobs in the food-processing industry (Molovin and Berkasovo Wineries, 'Agropapuk' in Kukujevci, 'Big Bull' in Bačinci, etc.) appeared in rural settlements and thus they became the gravitational point for the working age population of the municipality.

Table 5: Share of migrants according to their origin, in total migrants (in \%), according to the 2002 census in the border villages of the municipality of Šid.

\begin{tabular}{lccccccc}
\hline Settlement & Sum & $\begin{array}{c}\text { Same } \\
\text { municipality }\end{array}$ & $\begin{array}{c}\text { Other } \\
\text { municipality }\end{array}$ & $\begin{array}{c}\text { Other } \\
\text { countries**}\end{array}$ & $\begin{array}{c}\text { Former YU } \\
\text { republics }\end{array}$ & $\begin{array}{c}\text { Other } \\
\text { countries }\end{array}$ & Unknown \\
\hline Batrovci & 127 & 13.4 & 7.9 & 5.5 & 72.4 & 0.0 & 0.8 \\
Berkasovo & 753 & 35.3 & 8.2 & 2.4 & 52.7 & 0.5 & 0.9 \\
Bikić Do & 178 & 43.3 & 5.6 & 0.0 & 50.6 & 0.0 & 0.5 \\
Vašica & 875 & 18.3 & 4.0 & 2.1 & 75.1 & 0.3 & 0.2 \\
Ilinci & 349 & 19.5 & 7.2 & 2.9 & 69.9 & 0.0 & 0.5 \\
Jamena & 544 & 6.6 & 3.7 & 4.2 & 83.8 & 0.7 & 1.0 \\
Ljuba & 203 & 18.2 & 33.5 & 0.5 & 45.8 & 1.0 & 1.0 \\
Molovin & 128 & 21.1 & 11.7 & 4.7 & 61.7 & 0.8 & 0.0 \\
Morović & 1370 & 14.2 & 6.0 & 4.5 & 74.2 & 0.7 & 0.4 \\
Sot & 431 & 13.0 & 6.5 & 1.6 & 77.0 & 0.5 & 1.4 \\
Villages* & 4958 & 18.9 & 7.2 & 3.0 & 69.7 & 0.6 & 0.6 \\
Town (Šid) & 9307 & 30.3 & 10.0 & 6.1 & 52.1 & 0.8 & 0.8 \\
Municipality* & 21954 & 21.0 & 9.6 & 4.5 & 63.3 & 0.8 & 0.8 \\
\hline
\end{tabular}

Note: Villages ${ }^{\star}-10$ border villages of the municipality of Šid; Municipality ${ }^{\star \star}$ - all (19) settlements of the municipality of Šid; other republics ${ }^{\star \star \star}$ Montenegro (During the 2002 census, Serbia and Montenegro constituted Federal Republic of Yugoslavia (1992-2003)); Source: Statistical Office of the Republic of Serbia, 2004b, own calculations.

Shares of migrants in border villages of the municipality of Šid show that the majority of this part of the population of every village was settled during the 1990s, ranging from $27.8 \%$ in Jamena to $77.0 \%$ in Sot (Table 6). The period between 1946 and 1960 relates to the time of colonisation, which was conducted according to the Law on Agrarian Reform and Colonisation from 1945, by which population from hilly terrain of the former Yugoslavia (Gaćeša 1984, 113; Ćupurdija 1998, 225), i.e. from the same territory as from the observed decade (1990s), settled the territory of Vojvodina. The highest shares of population settled in that period were found in the southern border villages Jamena $(25.6 \%)$ and Batrovci $(23.6 \%)$.

In the migrant population, two groups have de facto been singled out: migrants who settled the border villages of the municipality of Sid for economical or political reasons, and migrants who came for personal reasons, i.e. marriage. In interviews, the following information was received: most people have no plans to return to the place from which they came; all of the interviewed people agreed that the border is characterised by great permeability, but they remember when there was no border. Most of the respondents, $73 \%$, who found themselves in the border villages of the municipality of Šid for economic or political 
Table 6: Share of migrants according to the time of immigration, in total migrants (in \%), according to the census 2002 in the border villages of the municipality of Šid.

\begin{tabular}{lcccccccc}
\hline Settlement & Before 1940 & $1941-1945$ & $1946-1960$ & $1961-1970$ & $1971-1980$ & $1981-1990$ & $1991-2002$ & Unknown \\
\hline Batrovci & 0.0 & 0.0 & 23.6 & 13.4 & 7.1 & 7.1 & 47.2 & 1.6 \\
Berkasovo & 0.9 & 1.1 & 7.4 & 11.8 & 9.3 & 11.2 & 54.8 & 3.5 \\
Bikić Do & 1.1 & 2.2 & 11.8 & 5.1 & 12.4 & 14.0 & 51.1 & 2.2 \\
Vašica & 1.3 & 0.3 & 8.3 & 4.9 & 3.9 & 7.9 & 71.9 & 1.5 \\
Ilinci & 1.1 & 1.4 & 18.3 & 12.0 & 12.9 & 8.3 & 44.1 & 1.7 \\
Jamena & 1.5 & 0.6 & 25.6 & 20.6 & 11.0 & 8.1 & 27.8 & 5.0 \\
Ljuba & 3.0 & 2.0 & 16.3 & 7.4 & 10.8 & 13.3 & 45.3 & 2.0 \\
Molovin & 1.6 & 1.6 & 6.3 & 17.2 & 17.2 & 12.5 & 43.0 & 0.8 \\
Morović & 0.7 & 0.5 & 12.9 & 11.2 & 8.8 & 9.1 & 55.5 & 1.2 \\
Sot & 0.5 & 0.2 & 5.1 & 3.2 & 4.9 & 6.7 & 77.0 & 2.3 \\
Villages $^{*}$ & 1.0 & 0.8 & 12.6 & 10.4 & 8.6 & 9.2 & 55.2 & 2.2 \\
Town (Šid) & 0.9 & 0.9 & 11.8 & 16.6 & 14.4 & 11.5 & 38.5 & 5.4 \\
Municipality* & 1.0 & 0.9 & 11.4 & 12.6 & 10.3 & 9.8 & 50.2 & 3.9 \\
\hline
\end{tabular}

Note: Villages ${ }^{\star}-10$ border villages of the municipality of Šid; Municipality ${ }^{\star \star}$ - all (19) settlements of the municipality of Šid; Source: Statistical Office of the Republic of Serbia, 2004b; own calculations.

reasons said that they had adapted themselves to the environment in which they live and that while going back could be personally satisfying, it was not economically justifiable. They said if there were appropriate economic conditions, they would support (about 84\%) the immigration of their children in directions further from the border. A small amount of respondents, about $12 \%$, sees the border as a zone of connecting, and not dividing of people. Most, $92 \%$, admit that there are the benefits to life next to the border. Most frequently they mention the prices of some products, which are lower on the other side of the border, and the profit they can make from selling different products to people from the Republic of Croatia. Similar phenomena have been determined in the other parts of the world (Fitzgerald et al. 1988; Timothy and Butler 1995; Sullivan and Kang 1997; Bygvra 1998; Wang 2004; Roper 2007).

A positive migration balance for the period between 1991 and 2002 has been determined in half of the border villages of the municipality of Šid, i.e. in all villages in which there was an increase of population and in the village of Sot (Table 7). The example of Sot confirms that settled population will not have the crucial importance for the development of the population in the future; this is confirmed by data received from research by Nikitović and Lukić (2010). The rate of migratory balance in border areas of Srem $(15.1 \%$ ) is quite similar to the value in the entire municipality $(14.1 \% 0)$. At present, the settled population has only covered depopulation.

Table 7: Migration balance of border villages of the municipality of Šid in the period between 1991 and 2002.

\begin{tabular}{lcccccc}
\hline Settlement & $\begin{array}{c}\text { Population } \\
\text { growth }\end{array}$ & $\begin{array}{c}\text { Average annual } \\
\text { growth rate } \\
\text { (in \%o) }\end{array}$ & $\begin{array}{c}\text { Migration } \\
\text { balance }\end{array}$ & $\begin{array}{c}\text { Average annual } \\
\text { rate of migration } \\
\text { balance (in \%o) }\end{array}$ & $\begin{array}{c}\text { Natural } \\
\text { population } \\
\text { growth }\end{array}$ & $\begin{array}{c}\text { Average annual } \\
\text { population growth } \\
\text { rate (in \%o) }\end{array}$ \\
\hline Batrovci & -38 & -9.1 & -24 & 24.5 & -14 & -33.6 \\
Berkasovo & 155 & 12.0 & 165 & 19.6 & -10 & -7.6 \\
Bikić Do & 37 & 10.7 & 39 & 15.5 & -2 & -4.8 \\
Vašica & 122 & 6.6 & 132 & 11.7 & -10 & -5.1 \\
llinci & -40 & -4.2 & -26 & 10.3 & -14 & -14.5 \\
Jamena & -158 & -10.8 & -147 & -3.5 & -11 & -7.3 \\
Ljuba & -22 & -3.5 & -17 & 3.9 & -5 & -7.4 \\
Molovin & -7 & -2.1 & -3 & 8.7 & -4 & -10.8 \\
Morović & 167 & 7.0 & 172 & 11.0 & -5 & -2.0 \\
Sot & -3 & -0.3 & 15.0 & 15.1 & -14 & -15.3 \\
Villages & 2559 & 15.1 & 2561 & 2.8 & -80 & 0.0 \\
Town (Šid) & 213 & 2.0 & 293 & 14.1 & -177 & -0.8 \\
Municipality* & 3938 & 9.4 & 4115 & & -4.7
\end{tabular}

Note: Villages ${ }^{\star}-10$ border villages of the municipality of Šid; Municipality** - all (19) settlements of the municipality of Šid; Source: Statistical Office of the Republic of Serbia, 2004a; 2004b; 2010; own calculations 


\subsection{Ethnic structure}

Ethnic minorities have been present in the municipality of Šid for centuries. In Berkasovo, Bačinci, a rural village in the municipality of Šid that is not a border village and in the town of Šid itself, the arrival of Rusyns was recorded in 1746 (Đurđev 1998; Ivkov 2006, 45; Drljača 2006). At the end of the $18^{\text {th }}$ century, the Diocese of Križevci (Croatia) moved the Rusyns from the Bačka settlements of Ruski Krstur and Kucura (Gavrilović 1956, 70; 1958; 1977, 153-215; Đerčan et al. 2010, 66). However, according to Beserminï (1937), Laboš $(1979,299)$ and Ramač $(2009,235)$, the Rusyns migrated from Krstur and Kucura, first to other settlements in Backa and from the beginning of the $19^{\text {th }}$ century to Srem and Slavonia, due to the troubles of the rural populace, which were caused by natural disasters, floods, drought and different field pests as well as due to the lack of arable land.

According to Sirácky (2002), Slovaks resettled in Slavonia and Srem in 1770. Stupavský (2010) reported the presence of Slovaks in Šid since 1810 and its existence within the military boundary with particular emphasis on the benefits of the town. According to Jankulov (1961), Slovaks inhabited the area in the middle of the $19^{\text {th }}$ century. As he writes, the first families immigrated from Slovakia and Hungary, and in the second half of the $19^{\text {th }}$ century they immigrated from Backa on a larger scale. At that time, the area was also settled by Jews. The colonisation of the Hungarians is miniscule compared to other parts of Vojvodina.

A series of political developments, including changes in states' borders and the formation of new states, rendered Vojvodina a territory of migrations throughout the $20^{\text {th }}$ century. These migrations have exerted a considerable impact upon Vojvodina's ethnic structure (Bjeljac and Lukić, 2008).

Table 8: Ethnic structure of population in the border villages of the municipality of Šid (in \%), according to the 1991 and 2002 censuses.

\begin{tabular}{|c|c|c|c|c|c|c|c|c|c|c|}
\hline \multirow{2}{*}{$\begin{array}{l}\text { Ethnic group } \\
\text { Census }\end{array}$} & \multicolumn{2}{|c|}{ Serbs } & \multicolumn{2}{|c|}{ Slovaks } & \multicolumn{2}{|c|}{ Rusyns } & \multicolumn{2}{|c|}{ Croats } & \multicolumn{2}{|c|}{ Others } \\
\hline & 1991 & 2002 & 1991 & 2002 & 1991 & 2002 & 1991 & 2002 & 1991 & 2002 \\
\hline Batrovci & 54.6 & 67.8 & 0.3 & 0.3 & No data & 1.3 & 38.3 & 28.4 & 6.8 & 2.2 \\
\hline Berkasovo & 54.7 & 68.5 & 2.3 & 1.7 & & 15.0 & 8.3 & 3.8 & 34.7 & 11.0 \\
\hline Bikić Do & 14.4 & 32.7 & 1.3 & 2.1 & & 47.6 & 13.0 & 11.6 & 71.2 & 6.0 \\
\hline Vašica & 63.9 & 86.2 & 2.4 & 1.4 & & 0.8 & 25.7 & 7.2 & 7.9 & 4.4 \\
\hline Ilinci & 93.3 & 96.3 & 0.2 & 0.4 & & 0.0 & 2.3 & 1.0 & 4.2 & 2.4 \\
\hline Jamena & 88.8 & 93.4 & 0.0 & 0.0 & & 0.3 & 4.6 & 2.8 & 6.6 & 3.5 \\
\hline Ljuba & 9.9 & 16.5 & 55.9 & 53.8 & & 0.4 & 28.2 & 22.7 & 6.0 & 6.6 \\
\hline Molovin & 84.3 & 87.6 & 0.0 & 0.3 & & 0.3 & 8.5 & 4.7 & 7.2 & 7.0 \\
\hline Morović & 61.9 & 87.3 & 0.5 & 0.4 & & 0.3 & 28.4 & 8.0 & 9.3 & 4.1 \\
\hline Sot & 4.4 & 43.0 & 4.2 & 3.5 & & 0.9 & 57.6 & 40.1 & 33.8 & 12.5 \\
\hline Villages* & 59.0 & 75.6 & 4.6 & 4.2 & & 4.1 & 21.5 & 10.4 & 14.8 & 5.8 \\
\hline Town (Šid) & 63.5 & 76.2 & 6.9 & 5.5 & & 4.2 & 8.8 & 4.4 & 20.8 & 9.7 \\
\hline Municipality** & 59.7 & 77.6 & 7.8 & 6.5 & & 3.4 & 16.7 & 5.4 & 15.8 & 7.2 \\
\hline
\end{tabular}

Note: Villages ${ }^{\star}-10$ border villages of the municipality of Šid; Municipality ${ }^{\star \star}$ - all (19) settlements of the municipality of Šid; Source: Statistical Office of the Republic of Serbia, 2003; own calculations.

In calculating the shares of certain ethnic groups in the total number of inhabitants of border villages of the municipality of Šid, some of the information that was obtained by interviewing the population has been confirmed. According to the census from 2002, Serbs were the majority in eight out of ten observed villages. Rusyns were the majority in Bikić Do, but significant presence of them (15\%) has also been determined in Berkasovo. Slovaks were the majority only in Ljuba (Figure 4). In order to determine whether and to what extent population trends affected the ethnic structure, data from the last two censuses have been compared, according to which the share of Serbs has been increased in all villages. This contingent of refugees has directly increased the ethnic homogeneity of population (Matijević et al. 2005, 119). This supports the assertion of Cordeiro $(1996)$ and Samers $(1998,124)$ that immigrants do not have to also be ethnic minorities.

Data on Rusyns from 1991 were not published. The share of the Croats has decreased in all villages, in Morović and Vašice by more than two thirds. According to their share in the entire population, in 1991 

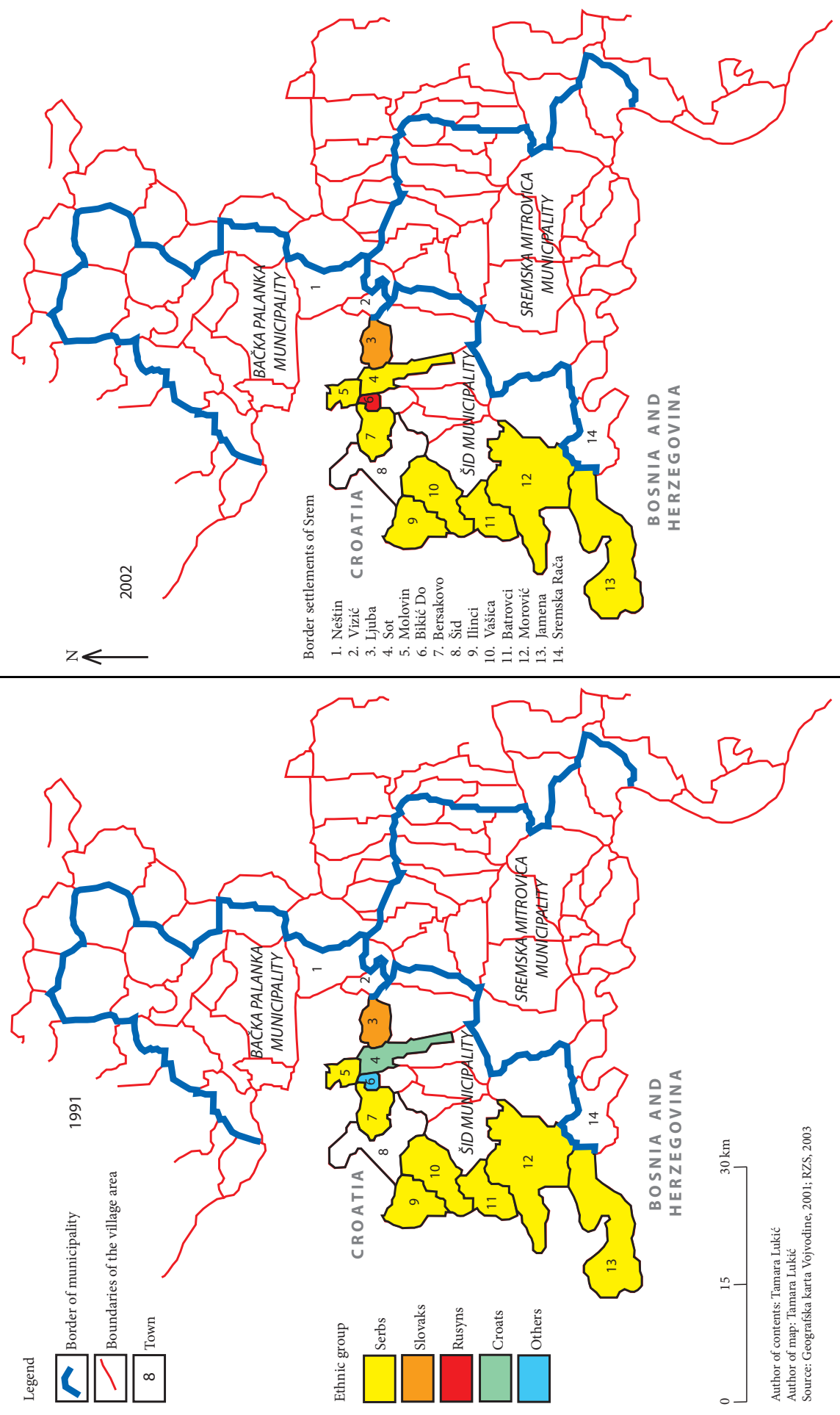
the Croats were the majority in Sot (Table 8). In interviews, it was explained that in 1990s, during the wars on the territory of Former Yugoslav Republics, Croats from villages in the municipality of Šid agreed to exchange their houses with Serbs from the territories of Croatia and Bosnia and Herzegovina. There is some mention of this by Kovačević et al $(2010,72)$.

Moreover, it was reported that in some villages certain political parties acted repressively, thereby motivating the Croatian population to migrate. The proximity of the border, i.e. Croatian territory, was a powerful and attractive motive for the Croatian population to move to nearby villages on the other side of the border; some of them already owned and cultivated land there.

\section{Conclusion}

Different tendencies in population trends were observed in ten border villages of the municipality of Šid in the period from the census in 1991 to the census in 2002. In four villages, there has been a determined increase in population. Analysing the local geography, it has been determined that those villages, unlike the others, are located either on busy roads or at crossroads. The more favourable position attracted people to settle those villages. Analysing natural population movement, it has appeared that from the four villages, only Bikić Do has positive population growth during half of the observed period. Accordingly, it has been concluded that the other villages had increased populations only as a result of a mechanical flow of population, which is confirmed by the fact that during the observed decade mass immigrations of people from the territories of former Yugoslavia to the region were taking place in the Federal Republic of Yugoslavia as a whole, and in the municipality of Šid specifically. Interviewing the refugee population for the purpose of obtaining information on their intentions about further movement, the most common answer received was that it depended on the economic situation. However, while visiting the field, the presence of different ethnic minorities was observed, which initiated analyses of data on ethnicity and the making of ethnic maps. The map confirmed that Bikić Do is the only village dominated by the Rusyn minority, which could also be one of the reasons only this border village has positive natural population growth. Drawing borders has positively affected the population numbers of border villages of the municipality of Šid, but the migration balance shows that a one-time 'population dosage' cannot obtain population growth in the conditions of negative trends observed at natural population movement.

\section{Acknowledgments}

This paper is part of the project No. 114-451-2644/2012-01 funded by the Provincial Secretariat for Science and Technological Development of the Vojvodina Province, Serbia.

The authors are grateful to the reviewers, whose comments and criticisms have ensured the quality of the paper.

\section{References}

Beserminï, G. 1938: Naselьovan€ Rusnacoh do Šidu. Ruski kalendar 1937. Ruski Kerestur.

Bjeljac, Ž., Lukić, V. 2008: Migrations on the territory of Vojvodina between 1919 and 1948. East European qarterly 42.

Bogdanović, Ž., Tomić, P., Romelić, J., Plavša, J., Lazić, L., Kralj, Đ. 1997: Opština Bačka Palanka, geografska monografija. Univerzitet u Novom Sadu, Prirodno-matematički fakultet. Novi Sad.

Bygvra, S. 1998: The road to the single European market as seen through the Danish retail trade: cross-border shopping between Denmark and Germany. The International Review of Retail, Distribution and Consumer Research 8. London. DOI: http://dx.doi.org/10.1080/09593969800000003

Cordeiro, A. 1996: Usages et contre-usages des statistiques du chomage des immigres. Hommes et migrations 1204.

Ćupurdija, B. 1998: Izveštaj o stanju kolonizacije Bajmoka 1946. godine. Zbornik Matice srpske za istoriju 58.

Ćurčić, S. 2001: Naselja Srema - geografske karakteristike. Matica srpska. Novi Sad. 
Ćurčić, S., Đuričić, J., Marjanović, V. 2002: Opština Sremska Mitrovica, geografska monografija. Univerzitet u Novom Sadu, Prirodno-matematički fakultet. Novi Sad.

Đerčan, B., Bubalo - Živković, M., Lukić, T. 2010: Demografske promene u pograničnim naseljima Srema na primeru Vašice. Zbornik radova Geografskog fakulteta u Beogradu 58.

Drljača, D. 2006: Rusnaci u etnorrafskih zapisoh/Rusini u etnografskim zapisima. Društvo za rusinski jezik, književnost i kulturu. Novi Sad.

Đurđev, B, S. 1998: Geografija stanovništva. Institut za geografiju Prirodno-matematičkog fakulteta. Novi Sad.

Đurđev, B., Arsenović, D., Dragin, A. 2010: Contemporary problems in studying population of Vojvodina Province. Acta geographica Slovenica 50-1. DOI: http://dx.doi.org/10.3986/AGS50105

Đurđev, S., B., Martinov-Cvejin, M., Penev, G., Jovanović, S., Stevanović, R. 2004: Demografska situacja u Vojvodini poslednje decenije XX i početkom XXI veka. Zbornik Matice srpske za društvene nauke 116-117. DOI: http://www.dx.doi.org/10.2298/ZMSDN0417199D

Fitzgerald, J., D., Quinn, T., P., Whelan, B., J., Williams, J., A, 1988: An analysis of cross-border shopping. The economic and social research institute Dublin, General research paper 137.

Gaćeša, N. 1984: Agrarna reforma i kolonizacija u Jugoslaviji 1945-1948. Matica srpska - odelenje za društvene nauke. Novi Sad.

Gavrilović, S. 1956: Rusini u Šidu od 1803-1848. Godišnjak Filozofskog fakulteta u Novom Sadu 1.

Gavrilović, S. 1958: Šid i šidsko vlastelinstvo (1699-1849). Zbornik Matice srpske za društvene nauke 16-19.

Gavrilović, S. 1977: Rusini u Bačkoj i Sremu od sredine XVIII do sredine XIX veka. Godišnjak Društva istoričara Vojvodine. Novi Sad.

Geografska karta Vojvodine. 2001: AP Vojvodina 1:450.000. Smederevska Palanka.

Hooghe, M., Trappers, A., Meuleman, B., Reeskens, T, 2008. Migration to European countries, A structural explanation of patterns, 1980-2004. International Migration Review 42-2. DOI: http://dx.doi.org/10.1111/ j.1747-7379.2008.00132.x

Ivkov, A. 2006: Demografska slika Vojvodine. Zadužbina Andrejević. Beograd.

Ivkov - Džigurski A., Bubalo - Živković, M., Lukić, T., Dragin, A., Ivanović, Lj., Pašić M. 2010: Demografski razvoj pograničnih opština Banata u drugoj polovini XX veka. Pokrajinski sekretarijat za nauku i tehnološki razvoj i Departman za geografiju, turizam i hotelijerstvo. Novi Sad.

Jankulov, B. 1961: Pregled kolonizacije Vojvodine u XVIII i XIX veku. Novi Sad.

Kovačević, T. 2006: Opština Subotica, geografska monografija. Univerzitet u Novom Sadu, PMF, Departman za geografiju, turizam i hotelijerstvo. Novi Sad.

Kovačević, T., Đurđev, B., Arsenović D. 2009: Movement of population in the Romanian border region, Case studing: Nova Crnja municipality. Geographica Timisiensis 18/1-2.

Kovačević, T., Zakić, L., Bubalo - Živković, M. 2010: Age-gender Structure of Croats in Vojvodina Province. Human geographies 4-2.

Laboš, F. 1979: Istoriя Rusinoh Bačkeй, Srimu i Slavoniï 1745-1918.

Lim, M., Metzler, R., Bar-Yam, Y. 2007: Global pattern formation and ethnic/cultural violence. Science 317. DOI: http://dx.doi.org/10.1126/science.1142734

Lukić, V, 2010: Population Dynamics and Commuting in Serbia. Spatial demography of the Balkans: trends and challenges, $4^{\text {th }}$ International Conference of Balkans Demography. Budva.

Lukić, V., Matijević, D. 2006: Opštine u Vojvodini sa najvećim udelom izbeglica - uticaj na dinamiku i strukturne karakteristike populacije. Zbornik Matice srpske za društvene nauke 121. Novi Sad.

Lukić, V., Nikitović, V. 2004: Refugees from Bosnia and Herzegovina in Serbia: A Study of Refugee Selectivity. International Migration 42-4. DOI: http://dx.doi.org/10.1111/j.0020-7985.2004.00296.x

Lukić, V., Tošić, B, 2011: Daily commuting - similarities and differences between Serbia and Slovenia. Acta geographica Slovenica, 51-2. DOI: http://dx.doi.org/10.3986/AGS51205

Machold, I., Dax, T., Meisinger, A. 2002: Youth participation in rural society in Maurau, Austria. In: T. Dax and I. I. Machold, Editors, Voices of Rural Youth: A break with traditional patterns? Wien.

Matijević, D, Tošić, B, Lukić, V. 2005: Uticaj migracija na populacione i funkcionalne promene sremskih opština. Glasnik Srpskog geografskog društva 85-1.

Meuleman, B., Davidov, E., Billet, J. 2009: Changing attitudes toward immigration in Europe, 2002-2007: A dynamic group conflict theory approach. Social science research 38-2. DOI: http://dx.doi.org/10.1016/ j.ssresearch.2008.09.006 
Nikitović, V., Lukić, V. 2010: Could Refugees Have a Significant Impact on the Future Demographic Change of Serbia? International Migration 48-1. DOI: http://dx.doi.org/10.1111/j.1468-2435.2009.00519.x

Ni Laoire, C. 2000: Conceptualising Irish rural youth migration: a biographical approach. International Journal of Population Geography 6.

O'Docherty Madrayo, L. 1988: The Hidden Face of The War in Central America. The sociology of involontary migration. Current sociology 36-2.

Penev, G. 1994: Demografska situacija u pograničnim naseljima Srbije. Stanovništvo 32/3-4.

Pilkington, H. 1998: Migration. Displacement, and Identity in Post-Soviet Russia. London.

Ramač, J. 2009: Slavko Gavrilović u istoriografiji o Rusinima u Južnoj Ugarskoj. Istraživanja 20.

Roper, S. 2007: Cross-border and local co-operation on the island of Ireland: An economic perspective. Political geography 26. DOI: http://dx.doi.org/10.1016/j.polgeo.2007.04.002

Samers, M. 1998: Immigration, 'ethnic minorities', and 'social exclusion' in the European Union: a critical perspective. Geoforum 29-2.

Sirácky, J. 2002: Dlhé hladanie domova. Martin.

Stanković, V. 2006: Opšte i metodološke informacije o popisu. Stanovništvo i domaćinstva Srbije prema popisu 2002. godine. Beograd.

Statistical Office of the Republic of Serbia. 2003: Stanovništvo, Popis stanovništva, domaćinstva i stanova u 2002, Nacionalna ili etnička pripadnost, 1. Republički zavod za statistiku. Beograd.

Statistical Office of the Republic of Serbia. 2004a: Stanovništvo, Popis stanovništva, domaćinstva i stanova u 2002, Uporedni pregled broja stanovnika - 1948, 1953, 1961, 1971, 1981, 1991 i 2002, podaci po naseljima, 9. Republički zavod za statistiku. Beograd.

Statistical Office of the Republic of Serbia. 2004b: Stanovništvo, Popis stanovništva, domaćinstva i stanova u 2002, Migraciona obeležja, podaci po naseljima, 8. Republički zavod za statistiku. Beograd.

Statistical Office of the Republic of Serbia. 2010: Broj rođenih i umrlih, po godinama, za period 1989-2002. Interna dokumentacija. Novi Sad.

Stockdale, A. 2002: Towards a typology of out-migration from peripheral areas: a Scottish Case Study. International journal of population geography 8. DOI: http://dx.doi.org/10.1002/ijpg.265

Stockdale, A. 2006: Migration: Pre-requisite for rural economic regeneration? Journal of Rural Studies 22-3. DOI: http://dx.doi.org/10.1016/j.jrurstud.2005.11.001

Stupavský, S. 2010: Slováci v Šíde 1810-2010. Matice slovenská v Srbsku. Báčsky Petrovec.

Sullivan, P.M, Kang, J, 1997: Information sources and motivational attributes of Canadian cross-border shoppers: a pilot study. International journal of commerce and management 7-1.

Timothy, D., J., Butler, R., W, 1995: Cross-border shopping - a North-American perspective. Annals of tourism research $22-1$.

VGI. 1982: Topografska karta 1:50.000 Bačka Palanka 377-3. Beograd.

VGI. 1982a: Topografska karta 1:50.000 Bijeljina 427-1. Beograd.

VGI. 1982b: Topografska karta 1:50.000 Bijeljina 427-2. Beograd

VGI. 1983: Topografska karta 1:50.000 Bačka Palanka 377-4. Beograd.

Vrecer, N. 2010: Living in Limbo: Integration of Forced Migrants from Bosnia and Herzegovina in Slovenia. Journal of refugee studies 23-4. DOI: http://dx.doi.org/10.1093/jrs/feq042

Vujadinović, S., Pavlović, M., Šabić, D. 2010: Integralni održivi razvoj na primeru lokalne geografske sredine. Glasnik Srpskog geografskog drušpštva XC-2. Beograd.

Wang, D. 2004: Hong Kongers'cross-border consumption and shopping in Shenzhen: patterns and motivations. Journal of retailing and consumer services 11. DOI: http://dx.doi.org/10.1016/S0969-6989(03)00014-6 